\title{
TANGGUNGJAWAB OTORITAS JASA KEUANGAN SOLO TERHADAP PENGELOLAAN DANA PENSIUN SYARIAH DI LEMBAGA DANA PENSIUN UNIVERSITAS MUHAMMADIYAH SURAKARTA ${ }^{1}$
}

\author{
Ani Yunita*, Reni Budi Setyaningrum, Muhammad Annas \\ *Fakultas Hukum, Universitas Muhammadiyah Yogyakarta. \\ J1. Brawijaya, Tamantirto, Kasihan, Bantul, 55183.Telp (0274) 387646. \\ aniyunita@umy.ac.id
}

\begin{abstract}
Muhammadiyah Surakarta Pension Fund Institution in practice there are still obstacles to fulfilling the provisions of the Financial Services Authority Regulation Number 33/ POJK.05/ 2016 and the lack of supervision of the Solo Financial Services Authority. This research method is a empirical yuridis or non doctrinal research with using the primary and secondary dates sources. Dates was collected with library research and analyzed by descriptive qualitative. Based on the results of the research and discussion, it is known that the implementation of the pension fund management at the Muhammadiyah University Surakarta Pension Fund Institution has been going well but there are still a few obstacles related to the absence of the Sharia Supervisory Board. The supervision of the Solo Financial Services Authority on the management of Muhammadiyah University Surakarta Pension Funds Institution as according to Article 6 of Law number 21 of 2011 is still not optimal from the legal aspects (regulations), law enforcement, facilities / infrastructure, society and culture.
\end{abstract}

Keywords: Sharia Pension Funds, UMS Pension Fund Institution, Solo Financial Services Authority.

\begin{abstract}
Abstrak
Lembaga Dana Pensiun Universitas Muhammadiyah Surakarta dalam prakteknya masih terdapat hambatan untuk memenuhi ketentuan Peraturan Otoritas Jasa Keuangan Nomor 33/POJK.05/2016 dan kurangnya pengawasan Otoritas Jasa Keuangan Solo. Metode penelitian hukum yang digunakan untuk mencapai tujuan penelitian hukum ialah yuridis empiris dengan menggunakan sumber data primer dan data sekunder. Teknik pengumpulan data dilakukan dengan teknik studi pustaka dengan mengkaji data dan dianalisis dengan menggunakan analisis deskriptif kualitatif. Berdasarkan hasil penelitian dan pembahasan diketahui bahwa pelaksanaan pengelolaan dana pensiun di Lembaga Dana Pensiun Universitas Muhammadiyah Surakarta telah berjalan baik namun, masih terdapat sedikit hambatan terkait dengan belum adanya Dewan Pengawas Syariah. Pengawasan Otoritas Jasa Keuangan Solo terhadap pengelolaan Lembaga Dana Pensiun UMS sebagaimana menurut Pasal 6 Undang-Undang Nomor 21 Tahun 2011 masih belum optimal dari aspek hukum (peraturannya), penegak hukumnya, fasilitas/sarana dan prasarana, masyarakat dan kebudayaan.
\end{abstract}

Kata Kunci : Dana Pensiun Syariah, Lembaga Dana Pensiun UMS, Otoritas Jasa Keuangan Solo.

\footnotetext{
${ }^{1}$ Hasil penelitian ini didanai oleh Lembaga Penelitian, Publikasi dan Pengabdian Masyarakat Universitas Muhammadiyah Yogyakarta pada tahun pelaksanaan 2018. Penelitian dilaksanakan dalam rangka kompetisi Penelitian Kemitraan.

460
} 


\section{A. Pendahuluan}

Keuangan syariah di Indonesia telah berkembang lebih dari dua dekade sejak beroperasinya Bank Muamalat Indonesia. Indonesia termasuk salah satu dalam sepuluh besar negara yang memiliki indeks keuangan syariah terbesar di dunia (Anonim, 2017). Saat ini total terdapat 416 kantor individual bank syariah, dengan total aset 174.393,15 Milyar (Anonim, 2017). Pertumbuhan lembaga keuangan syariah tersebut tentunya akan mendorong perkembangan dana pensiun syariah.

Dana pensiun syariah adalah dana pensiun yang dikelola dan dijalankan berdasarkan prinsip syariah, yakni bebas dari unsur yang dilarang syariat Islam, seperti riba, risywah, gharar, maisir dan batil (Al Alif dan Mardani, 2015). Dengan demikian, dana yang terkumpul dari iuran yang dibayar oleh peserta harus diinvestasikan pada instrumen investasi yang dibenarkan secara syariah. Misalnya, diinvestasikan pada efek-efek yang sesuai dengan prinsip syariah, yakni efek perusahaan yang sudah terdaftar dalam Jakarta Islamic Indek (JII) (Yuliani, 2017). Dana pensiun yang pengelolaannya sesuai dengan prinsip Islam akan lebih memiliki banyak manfaat bagi masyarakat, khususnya masyarakat yang loyal terhadap syariah. Pada hakikatnya program pensiun dapat menciptakan ketenangan kerja bagi karyawan karena kesejahteraan dihari tua akan dapat terjamin (Hasibuan, 2011).

Berdasarkan Pasal 6 Undang-Undang Nomor 21 tahun 2011 tentang Otoritas Jasa Keuangan (selanjutnya disebut dengan UU OJK), OJK mengambil alih tugas dan wewenang Menteri Keuangan dan Badan Pengawas Pasar Modal dan Lembaga Keuangan dalam melaksanakan fungsi, tugas, wewenang pengaturan dan pengawasan kegiatan jasa keuangan di sektor Pasar Modal, Perasuransian, Dana Pensiun, Lembaga Pembiayaan, dan Lembaga Jasa Keuangan Lainnya (Lestari, 2012). Dana pensiun syariah kemudian diatur lebih lanjut dalam Peraturan Otoritas Jasa Keuangan Nomor 33/POJK.05/2016 tentang Penyelenggaraan Program Pensiun Berdasarkan Prinsip Syariah (untuk selanjutnya disebut dengan POJK).

Pengembangan lembaga-lembaga pendukung dalam menopang lembaga keuangan syariah saat ini mempunyai peranan penting dalam mendukung kegiatan usaha dana pensiun syariah. Salah satu hal yang paling penting saat ini dalam menjalankan kegiatan usaha dana pensiun syariah adalah mengenai pengelolaan dana pensiun dari aspek legalnya. Hal ini perlu diketahui dan disosialisasikan kepada lembaga dana pensiun, pengelola dana pensiun syariah dan peserta yang mengikuti program dana pensiun syariah agar selalu 
mematuhi aturan hukum dan prinsip-prinsip syariah dalam melaksanakan pengelolaan dana pensiun.

Selama ini dalam pengelolaan dana pensiun masih belum memiliki kepastian hukum, tataran praktek belum berpedoman Peraturan Otoritas Jasa Keuangan Nomor 33/POJK.05/2016 tentang Penyelenggaraan Program Pensiun Berdasarkan Prinsip Syariah dan Undang-Undang Nomor 8 Tahun 1999 tentang Perlindungan Konsumen. Hal ini dilakukan agar para pihak dapat mengetahui, memahami dan melaksanakan dana pensiun syariah tersebut dengan itikad baik sehingga dalam pelaksanaanya tidak merugikan diantara kedua belah pihak.

Menurut Pasal 1 angka (1) UndangUndang Nomor 21 Tahun 2011 tentang Otoritas Jasa Keuangan disebutkan bahwa yang dimaksud dengan Otoritas Jasa Keuangan adalah lembaga yang independen dan bebas campur tangan pihak lain yang mempunyai fungsi, tugas dan wewenang pengaturan, pengawasan, pemeriksaan, dan penyidikan sebagaimana dimaksud dalam Undang-Undang ini (Hermansyah, 2011). Otoritas Jasa Keuangan berkedudukan di ibu kota Negara Kesatuan Republik Indonesia. Otoritas Jasa Keuangan dapat mempunyai kantor di dalam dan di luar wilayah Negara Kesatuan Republik Indonesia yang dibentuk sesuai dengan kebutuhan.
Otoritas Jasa Keuangan guna mengoptimalkan pelaksanaan tugas pengawasan seluruh industri jasa keuangan di seluruh Indonesia maka membuka kantor di daerah. Salah satu diantaranya adalah kantor wilayah Otoritas Jasa Keuangan Solo yang bertugas mengawasi pengelolaan industri keuangan di seluruh wilayah Surakarta dan sekitarnya, tidak terkecuali industri keuangan Dana Pensiun Syariah khususnya Lembaga Dana Pensiun Universitas Muhammadiyah Surakarta.

$$
\text { Dana pensiun Universitas }
$$

Muhammadiyah Surakarta adalah salah satu lembaga keuangan yang berada di wilayah kewenangan Otoritas Jasa Keuangan Solo dan segala kegiatan pengelolaan dananya berada dibawah pengawasan Otoritas Jasa Keuangan Solo. Otoritas Jasa Keuangan sudah tampak dalam praktiknya untuk memberikan perlindungan bagi lembaga jasa keuangan syariah dan konsumen, khususnya terkait dengan fungsi sistem pengawasan dalam meningkatkan kemitraan antara Lembaga Keuangan Syariah dan nasabah, namun belum menjalankan secara optimal. Otoritas Jasa Keuangan dalam menumbuhkan Syariah Compliance bagi Lembaga Keuangan Syariah dirasakan masih kurang optimal.

Tanggungjawab Otoritas Jasa Keuangan Solo dalam menjalankan pengawasan terhadap lembaga Dana Pensiun 
Universitas Muhammadiyah Surakarta telah berjalan baik namun pada kenyataannya bahwa pengawasan Otoritas Jasa Keuangan Solo terhadap Lembaga Dana Pensiun Universitas Muhammadiyah Solo masih belum optimal dan efektif dari perpesktif Pengelola Lembaga Dana Pensiun UMS sehingga perlu digali mengenai bagaimana pelaksanaan, hambatan-hambatan dan tanggungjawab Otoritas Jasa Keuangan dalam pengawasan terhadap pengelolaan dana pensiun Universitas Muhammadiyah Surakarta. Oleh karena itu, dapat ditemukan solusi dari permasalahan dan dapat memenuhi harapan masyarakat sehingga Lembaga Dana Pensiun UMS dapat berjalan baik dan Otoritas Jasa Keuangan Solo dapat berjalan lebih optimal dan efektif dalam wewenang pengawasan terhadap Lembaga Dana Pensiun Syariah.

\section{B. Kerangka Teori}

Salah satu teori yang menganalisa mengenai berlakunya hukum adalah teori efektifitas hukum. Teori efektifitas hukum dikemukakan oleh Soerjono Soekanto. Soerjono Soekanto berpendapat bahwa "efektif" adalah taraf sejauh mana suatu kelompok dapat mencapai tujuannya. Hukum dapat dikatakan efektif jika terdapat dampak hukum yang positif, pada saat itu hukum mencapai sasarannya dalam membimbing ataupun merubah perilaku manusia sehingga menjadi perilaku hukum. Persoalan efektifitas hukum dan pengidentikkan hukum tidak hanya dengan unsur paksaan eksternal namun, dapat melalui proses pengadilan. Ancaman paksaan merupakan unsur yang mutlak ada agar suatu kaidah dapat dikategorikan sebagai hukum, maka tentu saja unsur paksaan inipun erat kaitannya dengan efektif atau tidaknya suatu ketentuan atau aturan hukum (Soekanto, 1988).

Teori efektifitas hukum menurut Soerjono Soekanto adalah bahwa efektif atau tidaknya suatu hukum ditentukan oleh 5 (lima) faktor, yaitu (Soekanto, 2008): Faktor hukumnya sendiri (undang-undang), penegak hukum (yakni pihak-pihak yang membentuk maupun menerapkan hukum), Sarana atau fasilitas yang mendukung penegakan hukum, masyarakat, ( lingkungan dimana hukum tersebut berlaku atau diterapkan), dan faktor kebudayaan (sebagai hasil karya, cipta dan rasa yang didasarkan pada karsa manusia di dalam pergaulan hidup).

Penelitian tentang "Tanggungjawab Otoritas Jasa Keuangan Terhadap Pengelolaan Dana Pensiun Syariah di Lembaga Dana Pensiun Universitas Muhammadiyah Surakarta" sepengetahuan penulis belum ada. Penelitian yang dilakukan penulis sebelumnya mengenai Tinjauan Yuridis terhadap Pengelolaan 
Akad Syariah di Lembaga Dana Pensiun Muhammadiyah Yogyakarta. Penelitian ini berfokus pada pelaksanaan akad dana pensiun syariah di Lembaga Dana Pensiun Muhammadiyah. Penelitian lain dilakukan oleh Rodho Intan Putri Hasibuan dengan judul "Dana Pensiun Dilihat dalam perspektif hukum bisnis syariah" untuk mengetahui landasan fikih bagi pengembangan dan pengelolaan dana pensiun.

Perbedaan penelitian yang dilakukan penulis dengan Rodho Intan Putri Hasibuan bahwa penulis mengetahui pelaksanaan, hambatan-hambatan dan tanggungjawab Otoritas Jasa Keuangan dalam pengawasan terhadap pengelolaan dana pensiun Universitas Muhammadiyah Surakarta.

Dana Pensiun Universitas Muhammadiyah Surakarta dalam prakteknya masih terdapat hambatan untuk memenuhi ketentuan Peraturan Otoritas Jasa Keuangan Nomor 33/POJK.05/2016 tentang Penyelenggaraan Program Pensiun Berdasarkan Prinsip Syariah dan kurangnya koordinasi dengan Otoritas Jasa Keuangan Solo. Berdasarkan uraian tersebut maka mendorong penulis untuk melakukan penelitian dengan perumusan permasalahan bagaimana pelaksanaan pengelolaan dana pensiun di Lembaga Dana Pensiun Universitas Muhammadiyah Surakarta, apa saja hambatan-hambatan pengelolaan dana pensiun pada Lembaga Dana Pensiun Universitas Muhammadiyah Surakarta dan bagaimana tanggungjawab Otoritas Jasa Keuangan Solo dalam menjalankan wewenang pengawasan terhadap pengelolaan dana pensiun di Lembaga Dana Pensiun Universitas Muhammadiyah Surakarta.

Penelitian ini bertujuan untuk mengetahui pelaksanaan pengelolaan dana pensiun di Lembaga Dana Pensiun Universitas Muhammadiyah Surakarta, hambatan-hambatan pengelolaan dana pensiun pada Lembaga Dana Pensiun Universitas Muhammadiyah Surakarta, tanggungjawab Otoritas Jasa Keuangan Solo dalam menjalankan pengawasan terhadap pengelolaan dana pensiun di Lembaga Dana Pensiun Universitas Muhammadiyah Surakarta.

Urgensi penelitian ini adalah untuk mengkaji tanggungjawab Otoritas Jasa Keuangan Solo dalam pengawasan terhadap pengelolaan dana pensiun syariah dan pengembangan lembaga dana pensiun syariah di Indonesia yang merupakan kompetensi penulis di bidang pengembangan hukum ekonomi syariah.

\section{Metode Penelitian}

Jenis penelitian hukum yang digunakan dalam penelitian ini adalah jenis penelitian hukum sosiologis atau yuridis 
empiris. Sebagaimana yang dikemukakan oleh Soerjono Soekanto, penelitian jenis ini adalah penelitian yang memfokuskan terhadap identifikasi hukum dan efektifitas hukum (Sunggono, 2007).

Jenis penelitian yuridis empiris ini pada dasarnya dapat menggabungkan antara data yang didapatkan dilapangan dengan data yang didapatkan melalui penelusuran literatur terkait dengan topik yang menjadi fokus penelitian (Waluyo, 2002). Dalam hal ini penulis menggali informasi terkait dengan tanggung jawab Otoritas Jasa Keuangan dalam melakukan pengawasan terhadap pengelolaan dana pensiun syariah pada lembaga dana pensiun yang ada di Universitas Muhammadiyah Surakarta dan mengkomparasikan hasil penelitian lapangan tersebut dengan hasil penelusuran kepustakaan berupa literatur atau buku-buku serta peraturan yang berlaku terkait dengan topik penelitian.

Data primer dalam penelitian ini diperoleh dari hasil observasi dan wawancara dengan pengelola Lembaga Dana Pensiun Universitas Muhammadiyah Surakarta dan Kantor Otoritas Jasa Keuangan Solo. Data sekunder adalah jenis data yang mendukung dan menunjang kelengkapan data primer melalui bahan literature seperti buku-buku, jurnal, teoriteori, ataupun peraturan-peraturan yang terkait dengan topik penelitian ini. Dalam konteks penelitian ini peraturan yang dimaksud antara lain Undang-Undang Nomor 11 Tahun 1992 tentang Dana Pensiun, Undang Undang Nomor 21 tahun 2011 tentang Otoritas Jasa Keuangan dan Fatwa DSN Nomor 88/DSN-MUI/XI/2013 tentang Pedoman Umum Penyelenggaraan Program Pensiun Berdasarkan Prinsip Syariah.

Teknik pengumpulan data yang digunakan untuk memperoleh data primer ialah melalui observasi dan wawancara (Interview) secara langsung dengan pimpinan dan/atau staf Lembaga Dana Pensiun Syariah Universitas Muhammadiyah Surakarta dan pimpinan dan/atau staf Otoritas Jasa Keuangan Solo sehingga peneliti mendapatkan data yang dibutuhkan.

Data yang diperoleh baik dari penelitian kepustakaan maupun dari penelitian lapangan diolah berdasarkan analisis deskriptif kualitatif. Pengertian deskriptif adalah memberikan data secara jelas tentang keadaan atau gejala-gejala lainnya dan kualitatif ialah analisis terhadap data yang dinyatakan oleh responden dan narasumber yang kemudian diuraikan sehingga diperoleh suatu pengertian. Jadi, dalam penelitian ini akan menggambarkan bagaimana pengelolaan, hambatanhambatan dan tanggungjawab Otoritas Jasa Keuangan Solo dalam mengawasi 
pengelolaan dana pensiun di Lembaga Dana Pensiun Universitas Muhammadiyah Surakarta.

\section{Hasil dan Pembahasan}

\section{Pelaksanaan Pengelolaan Dana} Pensiun di Lembaga Dana Pensiun Universitas Muhammadiyah Surakarta

Dana Pensiun memiliki tugas untuk mengelola dan menginvestasikan dana yang dihimpun dari kontribusi yang dibayarkan oleh karyawan dan atau pemberi kerja dan membayarkan manfaat pensiun kepada karyawan di masa purnakaryanya. Lembaga Dana Pensiun bertanggungjawab kepada pemberi kerja melalui Dewan Pengawas untuk pengelolaan dana yang dikumpulkan sehingga pada waktunya dapat mencukupi dalam pembayaran manfaat pensiun kepada para peserta. Dana Pensiun agar mampu menjalankan fungsinya maka harus mengelola dan mengembangkan dana yang terkumpul dengan cara yang aman dan menguntungkan, salah satunya dengan melakukan investasi. Investasi yang dilakukan oleh Dana Pensiun harus sesuai dengan kebijakan investasi dari pendiri Dana Pensiun dan juga sesuai dengan ketentuan yang berlaku yaitu Peraturan Menteri Keuangan Nomor 199/PMK.010/2008 tentang Investasi Dana Pensiun.
Dana pensiun merupakan salah satu alternatif pendanaan bagi karyawan apabila mereka tidak produktif lagi bagi perusahaan. Berdasarkan Undang-Undang Nomor 11 Tahun 1992 tentang Dana Pensiun, bahwa dana pensiun adalah badan hukum yang mengelola dan menjalankan program yang menjanjikan manfaat pensiun. Manfat pensiun yang dimaksud adalah pembayaran berkala yang dibayarkan kepada peserta pada saat dan dengan cara yang ditetapkan dalam peraturan dana pensiun sebagaimana tertuang dalam Pasal 1 angka (1) dan angka (9) Undang-Undang Dana Pensiun. Berdasarkan definisi tersebut bahwa dana pensiun merupakan lembaga atau badan hukum yang mengelola program pensiun yang dimaksudkan untuk memberikan kesejahteraan kepada karyawan suatu perusahaan terutama yang telah pensiun.

Pasal 1 ayat ( 5) Peraturan Otoritas Jasa Keuangan Nomor 33/POJK.05/2016 tentang Penyelenggaraan Program Pensiun Berdasarkan Prinsip Syariah bahwa yang dimaksud dengan dana pensiun syariah yaitu dana pensiun yang seluruh kegiatannya diselenggarakan berdasarkan prinsip syariah. Hal ini berarti seluruh kegiatan dalam pengelolaan dana pensiun harus berdasar pada prinsip syariah yang telah ditentukan.

Penerapan syariah dalam lembaga Dana Pensiun sangat dimungkinkan, yaitu bahwa menggunakan skema yang bebas dari 
unsur-unsur yang dilarang dalam Islam, yaitu unsur maysir, gharar, riba, ryswah dan bathil. Dengan demikian, dana yang terkumpul dari iuran yang dibayar oleh peserta harus diinvestasikan pada instrumen investasi yang dibenarkan secara syariah. Misalnya, diinvestasikan pada efek-efek yang sesuai dengan prinsip syariah, yakni efek perusahaan yang sudah terdaftar dalam Jakarta Islamic Indek (JII). Adapun beberapa jenis portofolio instrumen investasi syariah yang sudah tersedia, yaitu: tanah, sukuk, deposito dan tabungan.

Salah satu lembaga dana pensiun yang mengelola dana sebagai tabungan jangka panjang yang dihimpun secara khusus dengan tujuan memberikan manfaat kepada karyawan pada saaat mereka mencapai usia pensiun adalah dana pensiun Universitas Muhammadiyah Surakarta (DAPEN UMS) yang bertempat di Gedung Induk Siti Walidah Universitas Muhammadiyah Surakarta. Dana pensiun dibentuk oleh Universitas Muhammadiyah Surakarta dengan nama dana pensiun Universitas Muhammadiyah Surakarta (DAPEN UMS).

$$
\text { Dana Pensiun Universitas }
$$

Muhammadiyah Surakarta didasari atas usaha untuk memberi jaminan terhadap kesinambungan kesejahteraan karyawan Universitas Muhammadiyah Surakarta (UMS) beserta keluarganya setelah purna bakti (pensiun) maka Rektor Universitas
Muhammadiyah Surakarta

(UMS) membentuk lembaga yang menangani jaminan tersebut yakni Dana Pensiun Universitas Muhammadiyah Surakarta pada tanggal 5 September 2008. Dana pensiun UMS didirikan berdasarkan SK Rektor Nomor 278/A.6-VII/SR/VI/2009 tertanggal 30 Juni 2009 dan telah disahkan oleh Mentri Keuangan dengan SK Nomor: KEP485/KM.10/2009 tertanggal 29 Desember 2009.

Dana Pensiun Universitas Muhammadiyah Surakarta didirikan untuk menyelenggarakan program pensiun manfaat pasti dengan alasan untuk mendapatkan kepastian jumlah manfaat pensiun bagi karyawan saat masa pensiun. Tujuan didirikannya Dana Pensiun Universitas Muhammadiyah Surakarta ialah memberikan kesinambungan penghasilan untuk kesejahteraan bagi peserta, janda/duda dan anak pada saat pegawai Universitas Muhammadiyah Surakarta mengalami pensiun.

Peserta Dana Pensiun Universitas Muhammadiyah Surakarta adalah semua karyawan tetap baik tenaga edukatif maupun tenaga administratif yang telah berusia 18 tahun atau telah menikah. Kepesertaan dimulai sejak karyawan terdaftar pada dana pensiun atau berhenti bekerja dengan mengalihkan haknya ke dana pensiun lain. Seorang peserta tidak dapat mengundurkan 
diri atau menuntut haknya dari dana pensiun apabila masih memenuhi syarat kepesertaan. Jika peserta meninggal dunia maka diberikan ke anak sampai anak tersebut berusia 25 tahun/ masih kuliah atau belum berpenghasilan.

Pada saat pembentukan Dana Pensiun Universitas Muhammadiyah Surakarta telah tercatat peserta sebanyak 687 orang dan hingga sekarang menjadi 833 orang peserta aktif dan 835 peserta yang pasif (telah pensiun). Peserta pensiun terdiri dari tenaga edukatif yang berusia 65 tahun dan tenaga administratif berusia 56 tahun. Karyawan Tetap Universitas Muhammadiyah Surakarta yang akan menjadi peserta dana pensiun Universitas Muhammadiyah Surakarta maka sejak awal menjadi karyawan tetap harus memenuhi syarat dengan memberikan Surat Keputusan Pengangkatan Karyawan Tetap UMS kepada Lembaga Dana Pensiun UMS.

Anggota aktif berarti anggota yang masih bekerja sedangkan anggota yang tidak aktif adalah anggota yang sudah purna tugas. Anggota dana pensiun ketika telah pensiun akan mendapatkan dana pensiun setiap bulannya selama seumur hidup. Untuk besaran yang diterima oleh setiap anggota dana pensiun yaitu karyawan UMS yang purna tugas ditentukan berdasarkan $2.5 \%$ (persen) faktor penghargaan (x) masa kerja (x) PHDP yaitu 80\% (persen) dari gaji pokok. Dana ini dibayarkan setiap tahun dan setiap tahunnya naik 5\% (persen).

Syarat Peserta Dana Pensiun Pasif atau telah pensiun maka harus memenuhi beberapa syarat sebagai berikut:

a. Foto Copy Surat Keputusan

Pengangkatan pegawai tetap UMS.

b. Foto Copy Surat Keputusan Terakhir Dan Pensiun

c. Foto Copy Kartu Tanda Penduduk

d. Foto Copy Kartu Keluarga

e. Foto Copy Nomor Pokok Wajib Pajak

f. Foto Copy Surat/ Buku Nikah

g. Foto Copy Buku Rekening Bank Pembangunan Daerah Jawa Tengah Syariah

h. Materai 6000 sebanyak 2 (dua) buah.

Peserta harus memenuhi dan melengkapi syarat-syarat tersebut. Peserta dana pensiun juga harus membayar kewajiban pembayaran iuran $4 \%$ (persen) dari gaji pokok tiap bulan. Peserta dana pensiun yang telah pasif atau akan pensiun maka wajib untuk menandatangani surat pernayataan dan memilih opsi yang diberikan oleh lembaga Dana Pensiun Universitas Muhammadiyah Surakarta untuk mengambil secara penuh atau berdasarkan persentase yang telah ditetapkan seperti opsi dibawah ini: 
a. Kurang dari Rp.400.000 (empat ratus ribu rupiah) perbulan maka diperbolehkan mengambil 100\% sekaligus.

b. $100 \%$ (seratus persen) bulanan penuh jika diatas Rp.400.000 (empat ratus ribu rupiah).

c. Diambil $20 \%$ (dua puuh persen) dan $80 \%$ (delapan puluh persen) bulanan diatas Rp. 400.000 (empat ratus ribu rupiah) perbulan.

Dalam mengelola program pensiun maka diperlukan komitmen pendiri dan pengelola untuk mengelola dana peserta secara hati-hati (prudent). Upaya yang dilakukan dengan cara meminimalkan segala kemungkinan moral hazard untuk kepentingan pihak tertentu yang tidak ada kaitannya dengan upaya peningkatan kesejahteraan peserta. Selain itu juga, dibutuhkan komitmen Pendiri untuk memenuhi kewajibannya baik akibat adanya masa kerja lalu maupun pendanaan untuk jangka panjang guna mencapai kekayaan yang cukup untuk membayar pensiun yang dilakukan melalui proses pengumpulan dan pengelolaan dana dengan memastikan bahwa investasi yang dilakukan sudah tepat dengan biaya seefisien mungkin.

Adanya program pensiun tesebut maka kesejahteraan dihari tua akan terjamin. Sementara bagi perusahaan itu sendiri, program pensiun dapat mendorong produktifitas pekerja atau karyawan karena dengan ikut program pensiun dapat menciptakan ketenangan kerja bagi karyawan yang mengetahui bahwa kesejahteraan dipurna tugasnya telah dijamin, pada gilirannya mereka akan loyal terhadap perusahaan serta akan bekerja secara produktif.

2. Hambatan-Hambatan Pengelolaan Dana Pensiun pada Lembaga Dana Pensiun Universitas

\section{Muhammadiyah Surakarta}

Data dari Otoritas Jasa Keuangan menyebutkan bahwa aset industri dana pensiun bertumbuh 7,06 persen pada tahun 2015 lalu menjadi 15,5 persen pada tahun 2016.

25 tahun setelah Undangundang Dana Pensiun diterbitkan maka industri ini hanya membukukan pertumbuhan yang tidak terlalu besar. Menurut data OJK, aset Industri Keuangan Non Bank (IKNB) sebesar Rp1.909,26 triliun per 31 Desember 2016 dan naik 13,64 persen dari tahun 2015. Pangsa aset industri dana pensiun sebesar 12,5 persen atau sekitar Rp 238,3 triliun. Dana kelolaan industri dana pensiun hanya $1,92 \%$ dari produk domestik bruto (PDB). Lebih kecil dari Thailand yang $6,6 \%$. Survei nasional yang dilakukan oleh Otoritas Jasa Keuangan (OJK) pada 2016 menunjukan indeks literasi keuangan dana pensiun baru sebesar $10,91 \%$, sedangkan indeks inklusi dana 
pensiun 4,66\%. Angka ini jauh di bawah indeks literasi nasional yang mencapai 29,66\%.(Anonim, 2018).

Penyebab masih rendahnya dana pensiun di Indonesia adalah sebagai berikut, Pertama, peraturan yang tumpang tindih mengenai dana pensiun. Perlu ada upaya dan kerja sama dari berbagai pemangku kepentingan agar dapat bersinergi dalam menyikapi persoalan ini. Pemerintah mewajibkan perusahaan mengikutsertakan karyawannya ke dalam program pensiun publik yaitu BPJS Ketenagakerjaan, sementara perusahaan sudah memiliki program pensiun perusahaan, aturan-aturan tersebut sehingga dapat membebani perusahaan. Kedua, adalah rendahnya kesadaran dan pemahaman masyarakat terutama generasi muda mengenai pentingnya mempersiapkan masa pensiun, saat ini sebagian besar generasi mudah mengalokasikan pendapatannya untuk membayar cicilan barang konsumtif seperti alat telekomunikasi dan kendaraan.

Dana Pensiun Syariah sebenarnya memiliki potensi besar untuk berkembang di Indonesia dengan sejumlah alasan (Yuliani, 2017) antara lain masih sedikit sekali proporsi masyarakat yang mau mengikuti program Dana Pensiun, kecuali pegawai negeri yang secara otomatis menjadi anggota Taspen dan Askes, berkembangnya lembaga keuangan dan bisnis syariah, tentunya sumber daya manusia yang bekerja dalam institusi tersebut menjadi pasar khusus yang jelas bagi nada pensiun syariah. Rasa percaya, rasa memiliki dan kesadaran masyarakat terhadap pentingnya idustri keuangan dan bisnis syariah yang terus membaik akan menajdi modal dasar yang penting untuk terus memperbesar konsumen dan nasabah yang loyal terutama bagi Dana Pensiun Syariah.

Perkembangan Dana Pensiun Syariah relatif tertinggal bila dibandingkan dengan industri keuangan syariah yang lain. Hal ini terjadi di antaranya disebabkan minimnya dukungan strategi dan regulasi. Hal ini dapat terlihat dalam beberapa hal sebagai berikut: (Nasution, 2006)

a. Dalam konteks strategi pengembangan industri lembaga keuangan syariah. Ketika perbankan, asuransi dan pasar modal syariah sudah memiliki dan masuk dalam road map strategi pengembangan masing-masing industri, Dana Pensiun Syariah belum disentuh sedikitpun dalam Kebijakan dan Strategi Industri Dana Pensiun Tahun 2007-2011.

b. Ketentuan investasi langsung dalam Undang-Undang Nomor 11 tahun 1992 tentang Dana Pensiun. Selama ini Dana Pensiun Lembaga Keuangan (DPLK) syariah mengeluhkan tentang produk investasi terikat (mudharabah 
muqayyadah/restricted investment) yang berpotensi besar tidak dapat dimasuki oleh DPLK syariah. Produk mudharabah muqayyadah merupakan produk bank syariah berupa investasi di bidang properti atau infrastruktur dengan nilai proyek yang sangat besar. Selama ini bank syariah kesulitan membiayai produk tersebut karena terbentuk dengan Batas Maksimum Pemberian Kredit (BMPK). Hal ini menjadi peluang investasi yang menarik bagi DPLK syariah. Jika Dana Pensiun Syariah masuk, berpotensi mendapat bagi hasil mencapai $20-30 \%$ dari return investasi jenis ini.

c. Dalam konteks regulasi. Jika perbankan, asuransi, obligasi dan reksa dana syariah sudah banyak memliki peraturan, baik berupa Undang-Undang, Peraturan Bank Indonesia, Dana Pensiun Syariah belum termuat dalam Undang-Undang Dana Pensiun sebagaimana halnya Undang-Undang Perbankan maupun Undang-Undang Perasuransian yang sudah mengesahkan lembaga Perbankan Syariah maupun Asuransi Syariah, namun dana pensiun syariah sudah memiliki Fatwa DSNMUI 88/DSN-MUI/XI/2013 tentang Dana Pensiun Syariah, termasuk ke dalam Kompilasi Hukum Ekonomi Syariah.
Lembaga Dana Pensiun UMS saat ini belum menerapkan dana pensiun dengan sistem syariah sebagaimana yang telah diatur Peraturan Otoritas Jasa Keuangan Nomor 33/POJK.05/2016 tentang Penyelenggaraan Program Pensiun Berdasarkan Prinsip Syariah. Namun demikian, investasi Dana Pensiun UMS telah menerapkan sistem investasi syariah berupa tanah, sukuk, deposito dan tabungan.

Berdasarkan hasil wawancara dengan Bapak Direktur Dana Pensiun UMS Drs. Muhroji menyampaikan bahwa pengelolaan dana pensiun Universitas Muhammadiyah Surakarta dalam menjalankan fungsi dan tugasnya ada beberapa hambatan. Hambatan Lembaga Dana Pensiun UMS dalam menerapkan Dana Pensiun Syariah yaitu Dewan Pengawas syariah dan pendiri belum ada Surat Keputusan dari Pihak yang berwenang. Beliau menyampaikan bahwa sebenarnya Dana Pensiun UMS sudah siap jika Dana pensiun UMS harus menerapkan sistem dana pensiun syariah. Hal ini juga disampaikan oleh Ibu Ifung salah satu staff Dana Pensiun UMS yang menyampaikan bahwa Dana Pensiun UMS hanya menunggu proses pengangkatan Dewan Pengawas Syariah dari MUI-Dewan Syariah Nasional. Dengan kata lain masih menunggu proses administrasi atau poses E Licensing dan $E$ Reporting. 
Dewan Pengawas syariah bertugas untuk mengawasi kegiatan operasional dana pensiun di Lembaga Dana Pensiun UMS yang diangkat oleh Majelis Ulama IndonesiDewan Syariah Nasional. Dewan pengawas harus memantau apakah kegiatan dana pensiun sudah menerapkan produk sesuai syariat islam atau belum sebagaimana yang dinyatakan dalam Peraturan Otoritas Jasa Keuangan Nomor 33/POJK.05/2016 tentang Penyelenggaraan Program Pensiun Berdasarkan Prinsip Syariah dan Fatwa DSN Nomor 88/DSN-MUI/XI/2013 tentang Pedoman Umum Penyelenggaraan Program Pensiun Berdasarkan Prinsip Syariah.

Dana Pensiun Universitas Muhammadiyah Surakarta untuk mengatasi hal-hal yang tidak diinginkan maka Lembaga Dana Pensiun UMS memberikan sosialisasi secara langsung atau leaflet terhadap pegawai tetap UMS setiap setahun sekali terkait prosedur, syarat dan hal-hal lain yang berkaitan dengan penyelenggaran dana pensiun Universitas Muhammadiyah Surakarta.

\section{Tanggungjawab Otoritas Jasa} Keuangan Solo dalam Menjalankan Wewenang Pengawasan terhadap Pengelolaan Dana Pensiun di Lembaga Dana Pensiun Universitas

\section{Muhammadiyah Surakarta}

Lembaga Dana Pensiun Universitas Muhammadiyah Surakarta sebelum tahun
2013 diberikan pengawasan oleh Kementrian Keuangan dan sejak tahun 2013 mulai diberikan pengawasan oleh Otoritas Jasa Keuangan. Lembaga Dana Pensiun UMS melakukan pelaporan kegiatan secara online ke Otoritas Jasa Keuangan (OJK).

Otoritas Jasa Keuangan ialah lembaga yang independen dan bebas dari campur tangan pihak lain yang mempunyai fungsi, tugas dan wewenang pengaturan, pengawasan, pemeriksaan dan penyidikan (Zaini, 2013). Otoritas Jasa Keuangan yang berada di wilayah Surakarta yaitu Otoritas Jasa Keuangan Solo sehingga OJK Solo yang memiliki kewenangan untuk menjalankan tugas dan fungsinya terhadap Lembaga Dana Pensiun Universitas Muhammadiyah Surakarta.

Ketentuan Pasal 6 Undang-Undang Nomor 21 Tahun 2011 tentang Otoritas Jasa Keuangan menyatakan bahwa Otoritas Jasa Keuangan melaksanakan tugas pengaturan dan pengawasan terhadap (Musjtari, 2017) kegiatan jasa keuangan di sektor Perbankan, kegiatan jasa keuangan di pasar modal, kegiatan jasa keuangan di sektor Perasuransian, Dana Pensiun, Lembaga Pembiayaan, dan Lembaga jasa keuangan lainnya.

Otoritas Jasa Keuangan untuk melaksanakan tugas pengawasan sebagaimana dimaksud dalam Pasal 6 maka Otoritas Jasa Keuangan mempunyai 
wewenang antara lain; (Astanti \& Juita, 2017) menetapkan kebijakan operasional pengawasan terhadap kegiatan jasa keuangan, mengawasi pelaksanaan tugas pengawasan yang dilaksanakan oleh Kepala Eksekutif, melakukan pengawasan, pemeriksaan, penyidikan, perlindungan konsumen, dan tindakan lain terhadap lembaga jasa keuangan, pelaku, dan/atau penunjang kegiatan jasa keuangan, memberikan perintah tertulis kepada Lembaga Jasa Keuangan dan/atau pihak tertentu, melakukan penunjukan pengelola statuter, menetapkan penggunaan pengelola statuter, menetapkan sanksi administratif terhadap pihak yang melakukan pelanggaran terhadap peraturan perundang-undangan di sektor jasa keuangan, memberikan dan/atau mencabut izin usaha, izin perseorangan, efektifnya pernyataan pendaftaran, surat tanda terdaftar, persetujuan melakukan keigatan usaha, pengesahan, persetujuan atau penetapan pembubaran, dan penetapan lain.

\section{Dana Pensiun Universitas}

Muhammadiyah Surakarta juga diawasi oleh Dewan Pengawas internal terdiri dari 4 (empat) Dewan Pengawas (Dosen UMS) yang berasal dari 2 (dua) dari pemberi kerja dan 2 (dua) dari peserta. Terdapat evaluasi kinerja pengurus tiap semester yang diawasi oleh Dewan Pengawas, Auditor Independen (KAP) 1 (satu) tahun sekali. 1 (satu) Dewan
Pengawas mengawasi 5 (lima) Dana pensiun.

Otoritas Jasa Keuangan melakukan pungutan senilai 0,045 dari jumlah asset dalam 1 (satu) tahun tiap triwulan sebanyak $4 \mathrm{x}$ (empat kali) atau berkisar Rp.100.000.000 (seratus juta rupiah) pertahun. Salah satu staff pengelola Dana Pensiun UMS mengatakan bahwa Otoritas Jasa Keuangan Solo kurang berkontribusi sehingga Otoritas Jasa Keuangan harus berbenah diri dan intropeksi diri. Beliau juga menyampaikan bahwa pungutan terlalu banyak sehingga keberatan. Pungutan tersebut berdasarkan aset berjalan dengan membayarkan ke rekening Otoritas Jasa Keuangan.

Otoritas Jasa Keuangan melakukan pengawasan secara aktif dan pasif. Laporan yang telah diajukan ke Otoritas Jasa Keuangan mengenai laporan tingkat kesehatan capital ratio (Rasio tingkat kesehatan). Laporan tersebut direview oleh 4 (empat) reviewer dari pihak pengawas Otoritas Jasa Keuangan yang terdiri dari Kepala Sub Bagian, Kepala, Bagian, Deputi dan Direktur Otoritas Jasa Keuangan. Parameter kesehatan bank dinilai berdasarkan pada tingkatan tidak sehat, kurang sehat,cukup sehat dan sehat. Dalam hal terdapat penyelesaian sengketa lembaga keuangan non bank melalui fasilitasi di Otoritas Jasa Keuangan dinyatakan belum 
berhasil diselesaikan maka akan dialihkan kepada pihak pengawas untuk diselesaikan. Pengawasan yang dilakukan bersifat pasif yaitu minimal 1 (satu) tahun sekali tergantung tingkat kesehatan Industri Keuangan Non Bank. Jika ada yang melanggar terkait pelaporan maka terdapat sanksi materi /unsur kesalahan tergantung kesalahannya.

Pengelola Dana Pensiun UMS menilai pungutan dari OJK tidak berbanding lurus dengan kinerja pengawasan yang dilakukan oleh OJK. Justru kementerian keuangan yang tidak mengambil pungutan dari pihak dapen dinilai lebih care terhadap pihak Dana Pensiun. Pengelola Dana Pensiun UMS mencontohkan bukti kepedulian kementerian keuangan adalah ketika dapen menghadapi masalah tertentu, pihak kementerian keuangan memberikan respon yang cepat. Hal ini karena di Kementerian Keuangan pada saat ada laporan atau keluhan akan ada auto record. Menurut Pengelola justru kementerian keuangan lebih up to date dibandingkan dengan Otoritas Jasa Keuangan.

Soerjono Soekanto berpendapat bahwa "efektif" adalah taraf sejauh mana suatu kelompok dapat mencapai tujuannya. Hukum dapat dikatakan efektif jika terdapat dampak hukum yang positif, pada saat itu hukum mencapai sasarannya dalam membimbing ataupun merubah perilaku manusia sehingga menjadi perilaku hukum. Tanggungjawab Otoritas Jasa Keuangan dalam melakukan pengawasan penyelenggaran dana pensiun syaraiah bisa dikatakan belum optimal. Hal ini dapat dianalisis dengan menggunakan teori efektifitas hukum menurut Soerjono Soekanto adalah bahwa efektif atau tidaknya suatu hukum ditentukan oleh 5 (lima) faktor, yaitu (Soekanto, 2008):

a. Faktor hukumnya sendiri (undangundang).

Faktor hukum mempengaruhi proses pengawasan terhadap penyelenggaraan dana pensiun syariah. Tugas dan kewenangan Otoritas Jasa Keuangan dalam menjalankan pengawasan sudah diatur dalam Pasal 6 Undang-Undang Nomor 21 Tahun 2011 tentang Otoritas Jasa Keuangan. Penyelenggaraan dana pensiun syariah juga telah diatur dalam Peraturan Otoritas Jasa Keuangan Nomor 33/POJK.05/2016 tentang Penyelenggaraan Program Pensiun Berdasarkan Prinsip Syariah meskipun diperlukan Undang-Undang Dana Pensiun Syariah yang menjadi payung hukum tersendiri. Hal ini terlihat bahwa fungsi pengawasan di Otoritas Jasa Keuangan Solo telah memiliki tugas kewenangan untuk melakukan pengawasan terhadap lembaga keuangan syariah. 
b. Faktor penegak hukum, yakni pihakpihak yang membentuk maupun menerapkan hukum.

Otoritas Jasa Keuangan berupaya untuk melakukan pengawasan kepada lembaga jasa keuangan syariah baik secara aktif maupun pasif, namun Otoritas Jasa Keuangan dalam melakukan pengawasan masih belum optimal. Sosioalisasi OJK terhadap Lembaga Jasa Keuangan Syariah dan masyarakat kurang meningkat sehingga masih banyak yang belum memahami tugas pengawasan OJK.

Peran strategis Dewan Pengawas Syariah (Sharia Supervisory Board). Dewan Pengawas Syariah memiliki peran dan tanggung jawab sentral melalui mekanisme kerjanya untuk memberikan keyakinan bahwa seluruh transaksi yang dilakukan oleh perusahaan tidak melanggar kaidah-kaidah syariah. Hal ini sangat penting dikarenakan tanggung jawab yang paling krusial dari dana pensiun syariah adalah menciptakan keyakinan kepada seluruh stakeholder-nya bahwa operasi institusi tersebut benar-benar sesuai dengan prinsip syariah. Untuk merealisasikan tujuan ini perlu untuk didorong independensi Dewan Pengawas Syariah (DPS) sekaligus memperkuat peranannya. Selain itu juga, memenuhi ketersediaan jumlah sumber daya manusia Dewan Pengawas Syariah dan sekaligus meningkatkan kualitasnya terutama dalam hal audit syariah dan internal shariah review perlu untuk ditetapkan.

c. Faktor sarana atau fasilitas yang mendukung penegakan hukum.

Dalam menjalankan fungsi pengawasan, Otoritas Jasa Keuangan memberikan fasilitas yang mendukung proses pengawasan terhadap lembaga jasa keuangan syariah. Pada prakteknya, terdapat pelaku jasa keuangan ataupun masyarakat terutama peserta Dana Pensiun yang belum mengetahui dan memahami proses pelaksanaan pengawasan Otoritas Jasa Keuangan.

Dalam hal ini pihak pengawas Otoritas Jasa Keuangan sudah melakukan pengawasan dengan memfasilitasi penyelesaian sengketa melalui fasilitasi dengan metode klarifikasi permasalahan terhadap pelaku jasa keuangan tetapi belum dilakukan secara optimal. Lembaga dana pensiun masih merasakan bahwa pengawasan Otoritas Jasa Keuangan belum dilakukan secara maksimal melakukan pengawaan karena kurangnya koordinasi antara Otoritas Jasa Keuangan dengan Lembaga dana pensiun Universitas Muhammadiyah Surakarta.

d. Faktor masyarakat, yakni lingkungan dimana hukum tersebut berlaku atau diterapkan.

Masyarakat/Peserta Dana Pensiun Universitas Muhammadiyah Surakarta harus 
memahami dan mengetahui proses penyelenggaran dana pensiun syariah di Dana Pensiun Universitas Muhammadiyah Surakarta sehingga peserta Dana Pensiun Syariah dapat mematuhi ketentuan Otoritas Jasa Keuangan.

e. Faktor kebudayaan, yakni sebagai hasil karya, cipta dan rasa yang didasarkan pada karsa manusia di dalam pergaulan hidup.

Otoritas Jasa Keuangan Solo dalam melakukan pengawasan terhadap penyelenggaran lembaga keuangan syariah bersifat rahasia dan tertutup guna menegakkan hukum di masyarakat. Artinya hasil dari pengawasan Lembaga Jasa Keuangan syariah tidak disebarluaskan informasinya kepada para pihak manapun. Masyarakat/Peserta dana pensiun syariah masih minim kesadaran hukumnya untuk melaporkan permasalahan-permaslahan yang terjadi mengenai lembaga keuangan syariah.

Budaya masyarakat dalam penyelesaian sengketa dana pensiun syariah memerlukan dukungan dari budaya masyarakat setempat. Budaya masyarakat sangat mempengaruhi berhasil atau tidaknya proses pengawasan terhadap sengketa yang dilakukan di Otoritas Jasa Keuangan. Seperti budaya damai yang terjadi di masyarakat, jika hal ini terdapat pada diri masing-masing pihak yang akan menyelesaikan sengketa, yaitu dari pihak konsumen dan lembaga jasa keuangan maka penyelesaian sengketa akan berjalan secara efektif.

Berdasarkan faktor hukum tersebut maka Otoritas Jasa Keuangan Solo dalam menjalankan pengawasan masih belum optimal. Hal tersebut dikaitkan dengan kelima faktor penegakan hukum menurut Soerjono Soekanto yaitu hukum (peraturannya), penegak hukumnya, fasilitas/sarana dan prasarana, masyarakat dan kebudayaan. Otoritas Jasa Keuangan dalam menegakkan syariah compliance bagi pelaku bisnis syariah di Lemabaga Keuangan Syariah harus menerapkan keempat cara mentaati hukum dan berupaya membangun kesadaran hukum dengan melakukan edukasi kepada para pelaku bisnis syariah di Lembaga Keuangan Syariah maupun kepada masyarakat.

\section{E. Simpulan dan Saran}

Berdasarkan hasil penelitian dan pembahasan diketahui bahwa pelaksanaan pengelolaan dana pensiun di Lembaga Dana Pensiun Universitas Muhammadiyah Surakarta telah berjalan baik namun, masih sedikit terdapat hambatan terkait dengan belum adanya Dewan Pengawas Syariah. Pengawasan Otoritas Jasa Keuangan Solo terhadap pengelolaan dana pensiun syariah sebagaimana menurut Pasal 6 UndangUndang Nomor 21 Tahun 2011 tentang 
Otoritas Jasa Keuangan masih belum optimal dari aspek hukum (peraturannya), penegak hukumnya, fasilitas/sarana dan prasarana, masyarakat dan kebudayaan.

Saran yang dapat diberikan oleh penulis terkait penelitian ini ialah Lembaga Dana Pensiun Universitas Muhammadiyah Surakarta sebaiknya segera melaksanakan pengelolaan dana pensiun dengan menerapkan prinsip-prinsip syariah sesuai dengan Peraturan Otoritas Jasa Keuangan Nomor 33/POJK.05/2016. Dewan Syariah Nasional dan Majelis Ulama Indonesia segera memberikan Surat Keputusan kepada Dewan Pengawas Syariah agar Lembaga Dana Pensiun UMS bisa melaksanakan pengelolaan dana pensiun syariah. Penulis juga memberikan saran agar Otoritas Jasa Keuangan lebih meningkatkan tugas dan kewenangannya sebagaimana UndangUndang Nomor 21 Tahun 2011 tentang Otoritas Jasa Keuangan agar Lembaga Dana Pensiun UMS dan Lembaga Keuangan Syariah lainnya dapat berjalan dengan baik.

\section{DAFTAR PUSTAKA}

Al Alif M. Nur, R \& Mardani. (2015). Aspek Hukum Lembaga Keuangan Syariah di Indonesia. Jakarta: Prenadamedia Group.

Astanti , D. (2017). Kewenangan Otoritas Jasa Keuangan Dalam Melakukan
Fungsi Pengawasan Pada Lembaga Perbankan Syariah. Jurnal Law and Justice. Vol 2(No.2).pp.164.

Hasibuan, R. (2011). Dana Pensiun Dalam Perspektif Hukum Bisnis Syariah. Jurnal Al Adalah. Vol X (No.1), pp.100.

Hermansyah. (2011). Hukum Perbankan Nasional Indonesia. Jakarta: Kencana.

Lestari, D. (2012). Otoritas Jasa Keuangan: Sistem Baru dalam Pengaturan dan Pengawasan Sektor Jasa Keuangan. Jurnal Dinamika Hukum. Vol 12 (No.3). pp. 557.

Musjtari, D. (2017). Efektifitas Pengawasan Otoritas Jasa Keuangan dalam Pembuatan Akad Syariah di Indonesia. Jurnal Hukum Ekonomi Islam. Vol 1 (No1).pp. 96.

Nasution,M. (2006). Pengenalan Eksklusif Ekonomi Islam, Jakarta: Kencana.

Soekanto,S. (2008). Faktor-Faktor yang Mempengaruhi Penegakan Hukum. Jakarta: PT.Raja Grafindo Persada.

Soekanto, S. (1988). Efektivitas Hukum dan Penerapan Sanksi, Bandung : CV. Ramadja Karya.

Sunggono, B. (2007). Metodologi Penelitian Hukum.,Cet.1. Jakarta: PT. RajaGrafindo Persada.

Waluyo, B. (2002). Penelitian Hukum Dalam Praktek. Sinar Grafika: Jakarta. 
Yuliani, M. (2017). Manajemen Lembaga Keuangan Non Bank Dana Pensiun Berdasarkan Prinsip Syariah. Jurnal Dinamika Penelitian. Vol. 17 (No. 2), pp. 232.

Zaini , Z. (2013). Hubungan Hukum Bank Indonesia sebagai Bank Sentral Dengan Otoritas Jasa Keuangan (OJK) Pasca Pengalihan Fungsi Pengawasan Perbankan. Jurnal Media Hukum. Vol 20 (No.2). pp.369.

Anonim, (2017), Roadmap Pengembangan Keuangan Syariah. Retrieved from http://www.ojk.go.id/kanal/syariah/ber ita dan kegiatan/publikasi/Pages/Roadmap Pengembangan Keuangan Syariah Indonesia-2017-2019.aspx.

Anonim, (2017), Statistik Perbankan Syariah, Retrieved from http:// www.ojk.go.id/id/ kanal/syariah/datadan-statistik/statistikperbankansyariah/Documents/Pages/St atistik Perbankan Syariah September 2017.

Anonim, (2018) Dana Pensiun Lembaga Keuangan: Menanti Generasi Sadar Pensiun, http://finansial.bisnis.com/read/20170 430/215/649410/danaphttp:/cms.bisnis .com /admin /article/edit/ 649410, diakses pada tanggal 11 September 2018.

\section{Daftar Peraturan Perundang-Undangan}

Republik Indonesia, Undang-Undang Nomor 21 Tahun 2011 tentang Otoritas Jasa Keuangan.

Republik Indonesia, Undang-Undang Nomor 8 Tahun 1999 tentang Perlindungan Konsumen.

Republik Indonesia, Undang-Undang Nomor 11 Tahun 1992 tentang Dana Pensiun.

Republik Indonesia, Peraturan Otoritas Jasa Keuangan Nomor 33/POJK.05/2016 tentang Penyelenggaraan Program Pensiun Berdasarkan Prinsip Syariah.

Fatwa DSN Nomor 88/DSN-MUI/XI/2013 tentang Pedoman Umum Penyelenggaraan Program Pensiun Berdasarkan Prinsip Syariah 